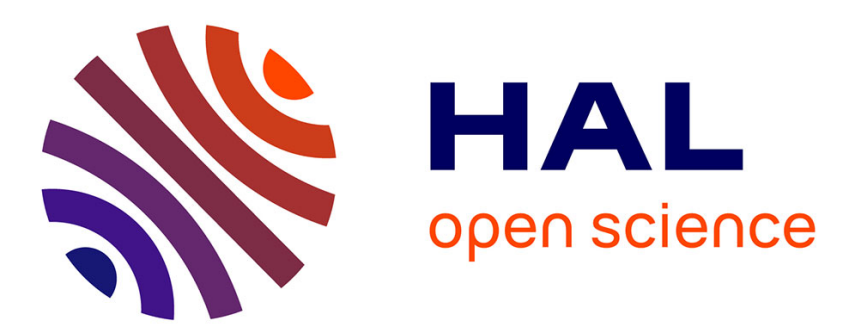

\title{
Leisure mobility and individuals' relationship to the living environment: a comparison between the Paris and Rome urban regions.
}

\author{
Hélène Nessi
}

\section{- To cite this version:}

Hélène Nessi. Leisure mobility and individuals' relationship to the living environment: a comparison between the Paris and Rome urban regions.. Environnement Urbain / Urban Environment, 2017, 12. hal-01675688

\section{HAL Id: hal-01675688 \\ https://hal.parisnanterre.fr/hal-01675688}

Submitted on 4 Jan 2018

HAL is a multi-disciplinary open access archive for the deposit and dissemination of scientific research documents, whether they are published or not. The documents may come from teaching and research institutions in France or abroad, or from public or private research centers.
L'archive ouverte pluridisciplinaire HAL, est destinée au dépôt et à la diffusion de documents scientifiques de niveau recherche, publiés ou non, émanant des établissements d'enseignement et de recherche français ou étrangers, des laboratoires publics ou privés. 


\section{Leisure mobility and individuals' relationship to the living environment: a comparison between the Paris and Rome urban regions.}

Mobilité de loisirs et rapport au cadre de vie : comparaison entre les régions parisienne et romaine.

Hélène Nessi

\section{Introduction}

1 Analyses of mobility have long focused on commuting and travel patterns, which could not be separated from issues of fluidity and congestion in transportation systems. From the 1990s, mobility began to be understood as an individual need and the focus shifted towards the regulation of individual travel behaviors. Mobility researchers, therefore, began studying the motives behind such travel. Mobility became an important research area and topic in the social sciences - some might say an entirely new paradigm (Urry, 2005). Some researchers have exclusively considered the influence of household demographic and socio-economic variables to explain mobility, while others have emphasized the impact of the morphology of living spaces (esp. density).

2 In this article, we address mobility from a different angle. We are interested in a type of mobility that is rarely taken into consideration: leisure mobility (including long-distance trips). We show that alongside other (socio-economic and spatial) factors, people's leisure mobility is shaped by how they value the relation to their living environment. We analyze the different ways households from the same neighborhood and/or of equivalent socio- 
economic status practice their territory. In short, we explore the connections between spatial practices and spatial context. It is based on empirical research conducted in nine residential zones located in two agglomerations, i.e., Paris and Rome. The use of a mixed quantitative and qualitative method allows both to quantify average mobility behavior, especially in terms of distances traveled (Holden and Norland, 2005; Orfeuil and Soleyret, 2002) and to understand the meaning that individuals give to their living environment. The analytical framework used here is based on an approach to mobility that is more cognitive and phenomenological and not only statistical; it focuses on the social subject/ actor, her position and the meanings she attributes to her practices and representations.

3 The first section recaps on the growing share of leisure mobility in overall mobility and points to the limits of the prevailing interpretations. The second section details the approach developed in the paper. In the third section, we construct a typology comprising five profiles based on how people value their living environment. And finally, we (quantitatively and qualitatively) explore mobility practices within each of the profiles and discuss in what ways one's stated relationship with one's living environment (hereafter: ROLE) affects one's leisure mobility.

Leisure mobility: The different types of leisure mobility examined in the quantitative analysis were: day trips, weekend excursions (one to three nights away from home) and holidays (more than four nights away from home). In the 81 semi-structured interviews conducted (qualitative analysis), we also included trips related to leisure activities taken during the week or at weekends (going to the cinema, theatre, cafés, restaurants, museum visits, amusement parks, shopping (other than for groceries), sporting and artistic activities, walks, meeting with friends and family, participation in festive or cultural events, involvement in an association or religious group).

\section{The growing share of leisure mobility in overall mobility and points to the limits of the prevailing interpretations.}

\subsection{Leisure mobility: an individual choice based on the idea of preference}

5 The growing importance of leisure in individual travel patterns has been observed across all Western countries including France and Italy, over the past few decades (Banister and Button, 1993). This type of mobility is unique in several ways: it is primarily based on choice and preference spatially dispersed across a territory and non-routine in nature.

\subsubsection{Increased leisure time and evolutions in the way it is organized}

While leisure is free and unconstrained time, it is not necessarily inactive or wasted time. It can be a period of self-training as far as educational values suppose learning something that can be of a cultural, social or sportive nature, among others (Pronovost, 2014; Robinson and al., 1988; Szalai, 1972). The activity itself is its own finality; it is accomplished for itself and involves active commitment. In this article, we focus on leisure activities requiring a choice and active participation, beginning with the fact that the subject has to go to the place of activity. 
7 The place leisure time takes in the timetable of households and their budget is increasing, which implies greater mobility. The decrease in the average working time is not the only factor triggering an increase in the number of trips made for leisure purposes. Other factors, such as aging population, increase in buying power, improved transport conditions or, still, new premises for leisure installations, have led to such an increase. In France, the high pre-1984 increase in holidays based on the "one full month in the same place" model, gave way to shorter holidays with a decrease in their average length according to the "more often, further, shorter" model between 1984 and 1990, then to the development of short stays and urban tourism accompanied by a diversification of destinations, as per the post-1990 "more often, more diversified, more cultural" model, to end up, from the 2000s onwards, with the "development of excursions and short-stay tourism" model throughout the year (Potier, 2006). Leisure mobility is generalized also the increase is unequal across social classes, the levels of income, education, and age (Potier, 2006; Viard and al., 2002; Dumazedier, 1988).

In the end, the Aubry laws on reducing working time (RTT) in France, accentuated the change in tourism behavior that had already begun with the continued reduction in the working time since the establishment of paid leave. $28 \%$ of employees $(50 \%$ among managerial staff and $13 \%$ of unqualified staff) testify to the fact that RTT has enabled them to go away more often for short periods or on long weekends (Dumontier and Pan Ké Shon, 2000).

8 As has been highlighted in the literature, a key factor in the way leisure trips are structured is the spatiality of social networks (Stauffacher and al., 2005). Visiting friends or family constitutes the main part of leisure trips as far as distance is concerned, due to the progressive dispersal of the members of a social network (Grefmeyer, 2007).

The Italians have an average of 30 holidays days per year compared to 46 in France. Said difference is mainly due to 10 RTT additional days off for French. In addition, the Italians school calendar shows rather short holiday period during the year and a long summer holiday: 2 weeks for Christmas, one for eastern and 9 weeks during summer time. In France, the school calendar is structured by a maximum of 8 weeks education period with holiday period in between. All Saint Day holiday period (10 days) and winter holiday (2 weeks in February) are added to traditional 2 weeks holidays (Christmas and spring break) and summer holidays (between 8 and 10 weeks).

\subsubsection{Increasing leisure mobility practices in France, Italy, and Europe}

10 The rapid development of leisure mobility practices in France is tied to the new temporalities of social life and to increases in the amount of time off and in purchasing power (Potier, 2006; Viard and al., 2002). As a result leisure mobility forms an increasingly large part of overall mobility (Potier, 2006). Analysis of long-distance mobility in France (Grimal, 2010) reveals an overall increase of 22\% in distances traveled between 1994 and 2008 , as a result from demographic growth and an increase in long-distance mobility ${ }^{1}$. While the share of long-distance mobility within overall mobility is marginal in terms of the number of trips - only $1.3 \%$ in 2008 -, it corresponds to $40 \%$ of the distances traveled. In $2008,83 \%$ of all long-distance trips correspond to leisure trips (vs. $17 \%$ for business trips). As regards private trips, the main travel motives consist of visits to family and friends (almost 35\%), holidays and travel to a secondary residence (almost 23\%), and other leisure trips ${ }^{2}$ (almost $14 \%$ ). "Visits to family and friends" and "other leisure motives" have increased most, with an average annual increase of $1.8 \%$ and $4.1 \%$ 
respectively. Conversely, holiday travel and travel to a secondary residence have increased only moderately, by about $0.7 \%$ per year. As regards the number of trips, the ranking of motives in 2008 is the same as in 1994, but the share of vacation travel has decreased in favor of "sociability-based" trips. Consequently, leisure mobility, which represents $60,2 \%$ of the overall mobility ${ }^{3}$ in 2008 , can no longer be overlooked when analyzing mobility.

11 In Italy, data interpretation is difficult since the national investigation from Istat concerning transport does only consider the number movement but does not take into account the distance traveled. From 1998 to 2008, the number of journeys (with a night outside) increased by $33 \%$. During that same period, an increase of $35 \%$ of travels during week-ends or holidays can be observed. Such increase is mainly due to short stay growth (1 to 3 nights), $+49 \%$ from 1998 to 2008 (Instituo Nazionale di Statistica, 2008). In 2008, repartition between short $(45,5 \%)$ and long $(41,1 \%)$ stay changes (Ibid.). Like in France, mobility increase can be explained by short stay increase. In France, mobility for short stay is associated with long-distance travel while in Italy short distances are preferred. In $2008,83,9 \%$ of trips done by Italians were done within the country ${ }^{4}$ and $16,1 \%$ done abroad mainly in Europe ${ }^{5}$. The attractiveness of small villages and regions in Italy is reinforced by the short holiday period and imply a reduced mobility in kilometers. The tourist locations in Italy are equipped with touristic infrastructures promoting local tradition: agritourism, albergo diffuso, seaside offer and food-and-wine tourism (Instituo Nazionale di Statistica, 2008). Italiens are looking for rest and try to stay with relatives to avoid hotel expenses (Ibid.) At the European scale, increases in the number of trips taken for leisure purposes combined with the shorter length of stays have also led to a nonnegligible increase in the distances traveled (Eurostat, 2011).

\subsubsection{Specific nature of leisure mobility: relatively unconstrained, spatially spread and non-routine}

12 Since the 2000s, research (Orfeuil, 1999; Plateau, 2008; ETHEL, 2004-2005) has pointed to the methodological limits of the available data on mobility. Most studies have focused solely on weekdays and the number of trips made without providing information about weekends or distances traveled (Orfeuil, 1999; Holden and Norland, 2005). In the few cases where weekends were included, only local trips within a radius of $100 \mathrm{~km}$ around the home were recorded and long-distance mobility was ignored despite the significant energy consumption involved. Newman and Kenworthy's famous curve (1989) for example solely takes into accounts intra-metropolitan trips and thus reflects only a small portion of distances traveled. It does not include mobility towards places outside the metropolis or weekend or holiday travel. Lastly, everyday leisure mobility involves trips that are more spread out and often carried out during off-peak hours, meaning that a car is often required (Méyère and al., 2006).

Besides, leisure trips have fewer constraints and are less dependent on certain forms of proximity than commuter travel. Non-work-related travel and especially leisure travel is less constrained and more largely based on individual choice. This individualisation process has resulted in a broad diversification of opportunities and motives for travel and of everyday life activities more generally. Further, leisure practices are not based solely on what is functionally available; they are often motivated by the desire to engage in an activity, visit a place and/or meet people. A cognitive approach is necessary to examine 
the important role played by the idea of preference. All of these facts highlight the specific nature of leisure mobility: mobility that is relatively unconstrained, spatially spread and non-routine.

\subsection{The drivers behind leisure mobility}

14 Research has shown that the demographic and socio-economic characteristics of households and spatial context always greatly influence leisure mobility.

\subsubsection{Demographic and socio-economic characteristics influence leisure mobility}

15 The propensity for spending free time only outside the home rather than at home is closely tied to the social and familial environment, household demographics, education level, age, and health (Potier, 2006; Paulo, 2006; Stead et al., 2000; Dieleman and al., 2002; Fan and al., 2009). The influence of socio-economic status is also visible from a very young age: the children of well-off households participate in more sporting, cultural and association-based activities and this tendency persists throughout adulthood, right up to retirement. The leisure activities of poorer households take place much more often at home (Paulo, 2006; Orfeuil, 2008). Social and cultural references impact the leisure activities that people adopt (Paulo, 2006). Economists underscore the influence of income and education, notably on trips that involve long-distance mobility, and the effects of socio-economic characteristics on the dispersal of households across a territory: because, in France as in Europe, the best-off households can choose to live in the city center with ease of access to the train stations and airports via the available public transportation networks (Coulageon and al., 2002; Paulo, 2006).

\subsubsection{Spatial context characteristics influence leisure mobility}

16 Other studies have shown that households with comparable socio-demographic indicators do not have identical spatial practices. This spatial approach contends that there is a close correlation between spatial context and leisure mobility. Density, and urban form more generally, are the main indicators used by researchers to explain mobility. High density accounts for shorter everyday travel distances given the proximity of services (Naess, 1995; Levinson and Kumar, 1997, Cervero and Kockelman, 1997; Newman et Kenworthy, 1989; Pouyanne, 2004; Naess, 2005; Limtanakool and al., 2006). The role of density in shaping everyday mobility has as such been proven. But this correlation has not been sufficiently studied in connection with leisure mobility (Titheridge and al., 2000). Some authors (Orfeuil and Soleyret, 2002; Plateau, 2008; ETHEL, 2004-2005) have shown that the inhabitants of downtown areas engage in more leisure travel during weekends than residents of peripheral zones with comparable incomes. These researches have shown one effect of residential location: living in a sparsely populated area results in longer everyday travel and more frequent car use, but less long-distance mobility.

17 Two Norwegian researchers have further documented these results (Holden and Norland, 2005) by showing that urban morphology has an impact on the direct consumption of energy associated with travel. Using multivariate analyses they have shown that the two main vectors of car or air-based leisure mobility are "housing density in residential areas" and "access to a private garden". Low density and access to a garden reduce mobility in all urban contexts. While the presence of a garden is obviously correlated to 
density and the urban morphology of a place, Holden and Norland have shown that all other things being equal, it has its own explanatory value. And Perrels (2005) stresses that city dwellers in densely populated cities whose leisure activities do not require much travel for shopping and cultural activities tend to develop a parallel "compensatory leisure mobility" to access green spaces (limited in downtown areas) or outdoor areas often far from their homes during holidays and daily leisure.

These authors use indicators related to so-called objective physical characteristics at the scale of a residential neighborhood $\left(\mathrm{m}^{2}\right.$ of green space within a given perimeter, population density, etc.). However, research into the behavior of inhabitants has shown that physical geographic space is not a decisive factor since inhabitants have different spatial practices in their living environment (Allen, 2007; Ramadier, 2007; Carpentier, 2007). These authors suggest that people's practices shape the spatial context and also are shaped by their relationship established with this context. These findings have led us to reflect on new ways to explain leisure mobility. Following on these studies, we contend that differences in leisure mobility practices partially result from the relationship that people have to their living environment.

\subsection{Stated and revealed relationships to one's living environment (ROLE)}

19 Research into mobility behavior based on residential location has shown that urban structure is particularly important since travel is constrained by the location of destinations outside the home, especially for work, school and, to a lesser extent, some shopping (Naess, 2005; Schlich and Axhausen, 2002). Leisure mobility appears to be less constrained, more temporally and spatially dispersed and less routine-based. It is also connected to influences other than the form of the city, notably preferences for places visited. That is why understanding how people value their living spaces can be supposed to be key to understanding leisure mobility. The analysis of the stated ROLE using a subjective analytical framework, allow understanding the choice of space practiced (revealed ROLEs) and travel (Dieleman and al., 2002).

\subsubsection{Escaping spatial determinism}

Some researchers have established a direct statistical correlation between residential location and mobility practices (Gordon and Richardson, 1989; Orfeuil and Soleyret, 2002; Holden et Norland, 2005), as well as between density of residential space and mobility practices (Levinson and Kumar, 1997; Halleux and Lambotte, 2006). A body of research sees everyday travel as a spatialized display of lifestyles and individual aspirations (Ohnmacht and al., 2009; Schlich and al. 2004). It focuses on the unique "orientations, attitudes and motivations" (Schlich et and. 2004) of an individual and the spatial context in which her practices occur, notably her practices leisure practices: these are less constrained and therefore reflect individual preferences to a larger extent (Schlich and al ., 2004; Lanzendorf, 2002).

21 Further, interactions between individuals and their environment raise the question of the variability of individuals' or groups' relationship with their environment. While forms of sociability vary greatly based on residential context amongst sociologically similar categories of people (Authier, 2007; Grefmeyer, 2007; Cailly, 2014), sociologically similar 
individuals in the same urban context do not always have the same practices (Chamboredon and Lemaire, 1970; Allen, 2007). Taking stock of this research, we would like to delve further into how living environments affect leisure-based mobility practices (Nessi, 2012).

\subsubsection{Using stated/revealed ROLEs to understand preferences}

The notion of preference is central when addressing the specific nature of "unconstrained", or less constrained, mobility. We need to delve deeper to understand the motivations behind such mobility practices, and this requires looking at more subjective indicators based on sensitive approaches (Lynch, 1981, p. 255-260) or social resources (Bonaiuto and al., 2006). Most of the empirical quantitative research into mobility ignores the relationship that individuals have to their living space, which nonetheless affects their specific use of space and their attraction to, or rejection of, certain places. By comparing the attitudes of individuals and the meaning they give to their living environment, some researchers have established a connection between ways of living ${ }^{6}$ (Cailly, 2014; Cailly et Dodier, 2007) and ways of occupying space (Chamboredon and Lemaire, 1970; Allen, 2007) or patterns of spatial mobility (Cailly, 2014; Couturier, 2014). From this body of research, we specifically draw on the idea that individuals are attracted to certain places and repelled by others based on their relationship with the environment. Such attraction and repulsion explain the choice of places visited and how they are used (Nasar, 2000). People tend to join specific social groups or places rather than others based on their relationship with space, individual judgment and available resources.

\subsubsection{Linking social representation and experience}

Research on the identity of places and spatial alignment highlights the influence of rational as well as subjective factors. We recommend thinking about leisure mobility in similar terms given that such mobility is less constrained and reflects individual preferences more than other motives as discussed in the first section. How, beside other factors (socio economic and spatial), urban context individual's representation structures their leisure mobility? Where social representations make it possible to bring out thought and behavioral models, they can help us to understand choices as regards leisure places. Under the effect of the decline of determinist paradigms, some authors point out the simplistic character of approaches by social representations and propose a return to the notion of experience (Dubet, 1994) and social experiences (Garfinkel, 1967). We are in line with this tradition and, to define the stated ROLE, we propose to use Jodelet's approach. Jodelet shows the importance and pertinence of linking social representation and experience. The ambiguity between these two phenomena questions the link between what is subjective and collective, individual and social.

The idea is to link two contradictory and complementary phenomena, i.e. social representations influenced by stable structures of significance, values, attitudes, and beliefs peculiar to culturally and socially defined groups, while apprehending fleeting states of personal experience in the daily living environment (Jodelet, 2006). This perspective, borrowed from Touraine's works (1995), uses phenomenology in order to establish an analytical framework that makes it possible to capture the human experience in a concrete space, where the subject's life unfolds. Through this link, it is possible to 
integrate symbolic dimensions referring to the relation to others and to the social order, linked to phenomenology but also to the material aspects of the actual reality. As such, apprehending representations in spatial contexts supposes to take into account the actual representations and the situations into which they fit, i.e. to take an interest in individual experiences in their relation to the way social representations function.

This theoretical alignment suggests noting down which elements of shared representations, in groups, are mobilized to build the meaning of the experience, and which standards and values are thwarted by the person's unique experience? The stated ROLE is, as such, the translation of the link of the experience and social representations, and contributes to the enrichment of the social representation approach: (1) by including emotional dimensions together with aspects of knowledge; (2) by considering that urban context and living environment are taken into account; (3) by introducing subjectivity into the negotiation of the necessary social alignment.

\subsubsection{Constructing an analytical framework to study stated ROLEs}

This theoretical framework suggests addressing how people value their living environment in terms of a trade-off between three main dimensions: functional (material), social (symbolic) and sensitivity (ideational).

1. The functional register, of material nature, is strongly linked to the representations of physical resources present in the living space. Therefore it is advisable to specify the importance of analyzing this register. Indeed, the presence of a resource is not perceived in the same way, depending on individuals, who can feel attraction or repulsion for a place. For example, living close to a train station or, still, a commercial center can be of value for some, yet not for others. Understanding the representations of the material offer prevents the idea of a mechanical effect, between the presence of a resource and its utilization or appropriation, from being established (Bonaiuto, 2003).

2. In the works establishing the link between relation to space and spatial alignment, the social register, of a symbolic nature, is essential in understanding why one chooses to frequent specific places. In their living space, residents seek an environment, which is close to their values and status (Chamboredon and Lemaire, 1970; Allen, 2007; Authier, 2008; Cailly, 2014). For example, residents investing in a local network of associations or, still, the presence of friends or family near their home can explain why they choose to be deeply rooted and therefore to limit their movements during weekends.

3. The last register that of the relation to space of an ideal and subjective nature is tackled by experience through phenomenology and is linked to social representations (Jodelet, 2006). The place of spatial experience accumulated during the life trajectory in this register, makes spatial alignment easier, by analogy with other places where one lived and by the simple knowledge of places already frequented and what they represent socially (Levy, 2003; Feildel, Martouzet, 2014). Individuals integrate the places they know (residential trajectories, frequented places), which then constitute a heritage of spatial experiences. This ease of alignment is not carried out only by analogy with spatial markers, but also by analogy with feelings of well-being or malaise experienced in the space, and with feelings in general, which refers to a subjective level in the relation with the environment of the nature of the sensitivity register.

27 We have developed a framework based on the representations of these three registers to analyze the qualitative interviews. This has allowed us to identify 19 characteristics within these three dimensions and to define five profiles of individuals based or their stated ROLEs. This approach to analyzing people's stated ROLE allows individuals to be 
positioned within three logics of action: the sensitivity, social and functional. The weight that individuals assign to the three registers helps explain different types of mobility.

As discussed above, we need to take into account the spatial context as well as the stated ROLE in order to understand leisure mobility. In the remainder of this article, we elaborate on how stated ROLEs affect the choice of places one attend and explain one's a particular type of mobility. In order to as much as possible avoid self-justifications or export reconstructed rational explanations, interviewees were first questioned on their ROLEs without any reference to their mobility. The revealed ROLE and stated ROLE (reflected in their declarations on the places they value or avoid, etc.) are thus constructed as distinct variables. We will now test our hypothesis about a connection between people's stated ROLE and their type of leisure mobility (distances traveled and places visited).

\section{Using hybrid methods and a comparative approach}

These results are based on a Ph.D. thesis (Nessi, 2012). To control and measure the influence of various indicators, we chose to Study a sample composed of households with young children in various locations (centre, peri-center, peri-urban) in Ile-de-France and Rome and apply a mixed method with qualitative, quantitative and contextual analyses.

\subsection{Focus on households with young children between the different neighborhoods having comparable income}

In our overview of the literature on mobility and on leisure mobility more specifically, we noted the influence of demographic and socio-economic indicators. In particular, household size and structure strongly impact people's activities, travel and the distances covered. To control for the demographic variable, we chose to study only households with young children (in which the adults were between 30 and 45 years old). To understand the specific influence of the stated ROLE on one's leisure mobility, we controlled the socio-economic indicators (education level, income, socio-economic classification), as well as geographic location (center, peri-center, peri-urban), which are presented in some research as explanatory criteria for leisure mobility. To control the economic indicator, we have selected median average income neighborhood and interviewed three types of populations (equal proportion): (1) high (2) average and (3) low-income, defined from the income corrected by the consumer unit of the household (INSEE).

\subsection{Comparative approach: nine fieldwork sites in two agglomerations}

31 While the connection between spatial context and leisure mobility has already been tested in some Northern European cities (Williams and al., 2000; Naess, 1995, 2005; Holden and Norland, 2005), it has never been studied in southern European cities. That is why we chose the Roman agglomeration in addition to the Parisian agglomeration for our empirical investigation. These two metropolises have many similarities:

1. both of these capital cities are very mono-centric;

2. both are major tourist destinations; 
3. both are undergoing classic urban transformation, with a shift of the population from the centre towards the periphery and a spatial dispersion of housing;

4. in terms of airport service, they have similar infrastructure.

These shared features are important for testing our hypotheses because they directly impact demand for transportation in terms of origin/destination), leisure travel for the resident population), the residential travel of households) and ease of access to air travel (for number (4). We should also note that the compact urban form in central Rome makes it similar to inner-city Paris. Rome's so-called “consolidated" area is also similar to Paris's inner suburbs. Lastly, like the outer suburbs of the Paris region, the so-called city "under transformation" spread across the agro romano comprises a dispersed urban fabric, a much less dependable transport service and a comparable rate of motorisation. Appropriate sectioning, therefore, makes it possible to create comparable scales.

Despite the similarities between the two agglomerations, however, there are also some major differences:

1. The quality of public transport networks is very different. The Parisian network is much denser and more interconnected than the Roman network. This is particularly the case for heavy transport infrastructure like the metro, tramway and rail system (including the RER service). The quality of public transport networks influences the motorization of households and their likelihood of using an automobile

2. The climate is much warmer and sunnier in Rome than in the Ile-de-France. These differences are also important for testing our research hypotheses since climate affects the likelihood of using nearby green spaces during the weekends.

3. The Roman agglomeration has remarkable natural amenities, notably its proximity to the sea and the living environment offers those who live in the center access to very rich and diverse natural surroundings within a radius of $30 \mathrm{~km}$ around Piazza Venezia, the center of historic Rome.

4. There is a strong distinction between the use of public place and as for socialization.

34 We selected central, peri-central and peri-urban fieldwork sites in both agglomerations Six sites were selected in the Ile-de-France region (Figure 1): two in the center (Paris-La Chapelle / L'Enclos St Laurent and Paris-La Réunion), two in the peri-center (LimeilBrévannes and Sartrouville) and two peri-urban sites (Thillay and Emerainville). In each location type, one of the sites has good rail service and the other has limited or no service. In Rome (Figure 2), three fieldwork sites were selected: Testaccio in the center, near a railway station; Pietralata in the peri-center, also with railway services; and Cinquina in the peri-urban zone, which is not on the rail network. Studying peri-urban and central neighborhoods concomitantly truly adds value, since most of the research into practices and ways of living has looked only at one of the three types of locations and therefore does not allow to examine whether some practices are specific to the residents of central, peri-central and peri-urban areas. 


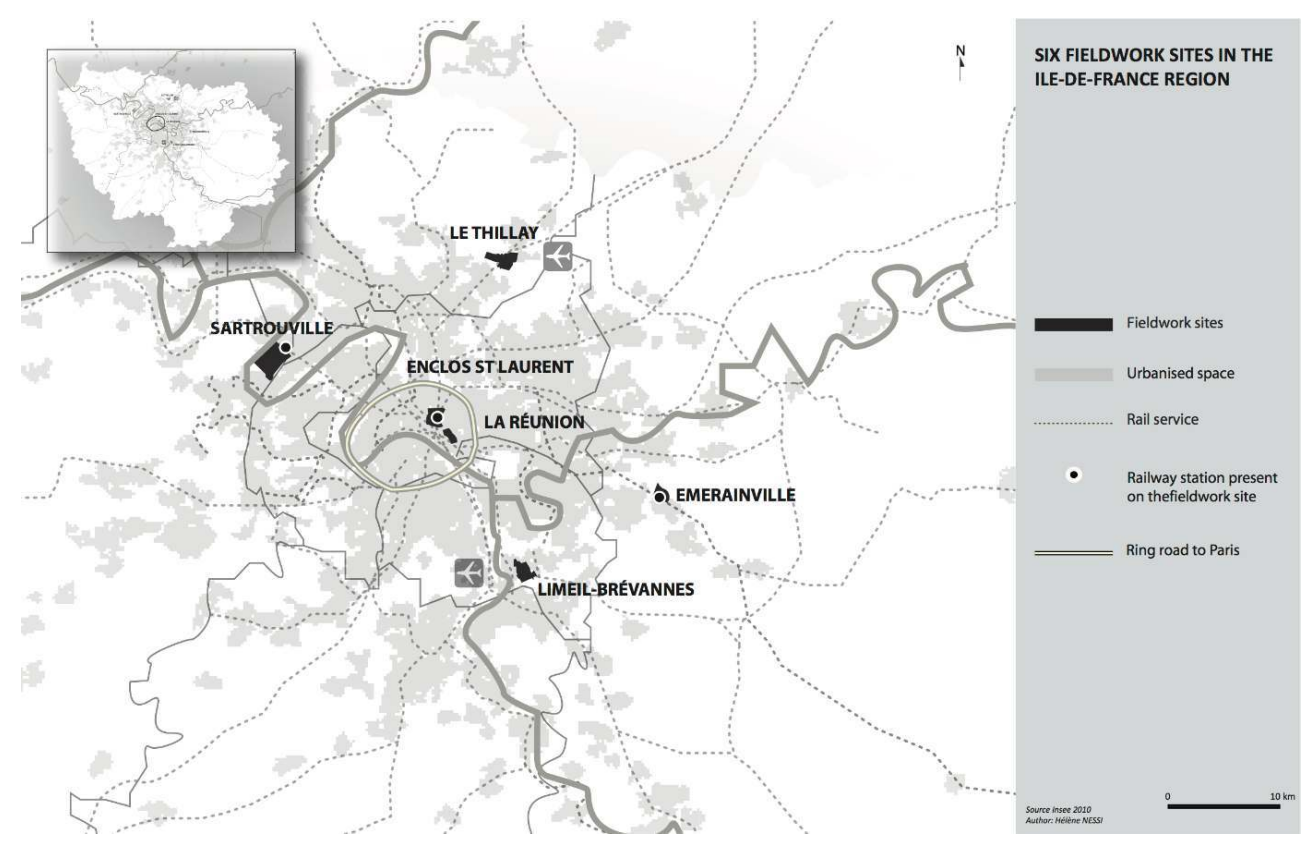

Source : Insee 2010

Figure 2: Three fieldwork sites in Rome

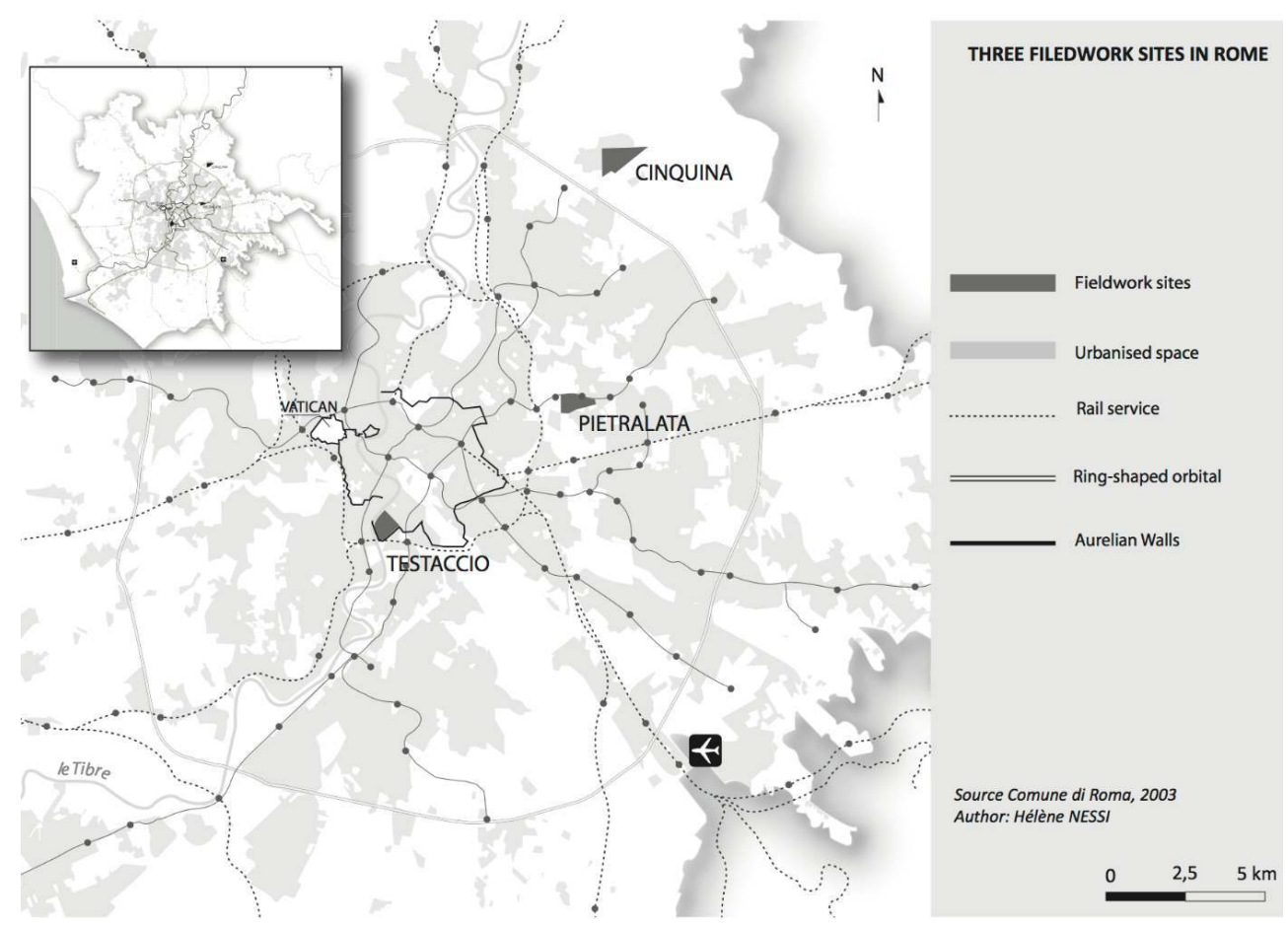

Source : Comune di Roma, 2003

We began by selecting specific sites at the neighborhood scale; we closely observed and described them as part of a contextual analysis, which took into account the different scales (dwelling, neighborhood, agglomeration) and the multiple characteristics that defined them. This analysis addressed the three dimensions identified above: functional 
resources (the organization of space (Table 1): density, road network configuration, presence and accessibility of transport services, infrastructures, equipment, services, commercial establishments, cafes and restaurants); social resources (demographic data, presence of associations, proximity to family and friends) and sensitivity characteristics (presence of nature, urban morphology, built environment).

Table 1: Comparison of contextual data from nine fieldwork sites

\begin{tabular}{|c|c|c|c|c|c|c|c|c|c|}
\hline \multicolumn{2}{|l|}{ SITES } & Population & $\begin{array}{l}\text { Surface } \\
\text { (ha) }\end{array}$ & $\begin{array}{l}\text { Population } \\
\text { density } \\
\text { hab./ha }\end{array}$ & $\begin{array}{l}\text { Green } \\
\text { space } \\
\text { en ha }\end{array}$ & $\begin{array}{l}\text { Green } \\
\text { space } \\
(\%)\end{array}$ & $\begin{array}{l}\text { Rail } \\
\text { services }\end{array}$ & $\begin{array}{l}\text { Commercial } \\
\text { establishments }\end{array}$ & $\begin{array}{l}\text { Sample } \\
\text { (nb. } \\
\text { people) }\end{array}$ \\
\hline \multirow{3}{*}{ Centre } & La Chapelle & 62280 & 212 & 293 & 4 & $2 \%$ & $\begin{array}{l}\text { Very } \\
\text { good } \\
\text { service }\end{array}$ & Good & 210 \\
\hline & La Réunion & 16318 & 61 & 267 & 2,5 & $4 \%$ & $\begin{array}{l}\text { Limited } \\
\text { service }\end{array}$ & Good & 214 \\
\hline & Testaccio & 8358 & 66 & 126 & 13 & $19 \%$ & $\begin{array}{l}\text { Good } \\
\text { service }\end{array}$ & Good & 250 \\
\hline \multirow{3}{*}{$\begin{array}{l}\text { Peri- } \\
\text { centre }\end{array}$} & Sartrouville & 16692 & 180 & 93 & 8 & $4 \%$ & $\begin{array}{l}\text { Good } \\
\text { service }\end{array}$ & Limited & 217 \\
\hline & $\begin{array}{l}\text { Limeil- } \\
\text { Brévannes }\end{array}$ & 11627 & 294 & 40 & 135 & $46 \%$ & $\begin{array}{l}\text { No } \\
\text { service }\end{array}$ & Low & 224 \\
\hline & Pietralata & 23300 & 180 & 129 & 99,5 & $52 \%$ & $\begin{array}{l}\text { Limited } \\
\text { service }\end{array}$ & Limited & 250 \\
\hline \multirow{3}{*}{$\begin{array}{l}\text { Peri- } \\
\text { urban }\end{array}$} & Emerainville & 7152 & 165 & 43 & 37 & $22 \%$ & $\begin{array}{l}\text { Limited } \\
\text { service }\end{array}$ & Low & 214 \\
\hline & Le Thillay & 4011 & 394 & 10 & 209 & $53 \%$ & $\begin{array}{l}\text { No } \\
\text { service }\end{array}$ & Low & 201 \\
\hline & Cinquina & 8717 & 90 & 97 & 43 & $48 \%$ & $\begin{array}{l}\text { No } \\
\text { service }\end{array}$ & Limited & 250 \\
\hline
\end{tabular}

\subsection{Mixed method: qualitative, quantitative and contextual analyses}

To understand the individual representations and the experience on their living environment and practices with a specific focus on ROLEs, we then interviewed households within these different urban spaces using a qualitative method (81 semistructured interviews: 9 per fieldwork site). Taking a qualitative approach allowed us to grasp the meanings and values attributed to specific places, the situations in which take place the representations and the attachment to place and to understand the complexity and diversity of practices. As such, these interviews make it possible to analyze individual 
experiences in their relation with social representations, and also to understand whether residential rooting is subjected or chosen. The qualitative approach also helped to specify the structuring elements of the representations shared within the groups and mobilized to build the meaning of the experience. These various elements constitute the quantitative analyze grid (Table 2) to build the typology of profiles of the stated ROLE. Finally, prioritizing these elements and determining the degree to which they influence the different profiles on mobility practices is impossible with aqualitative approach. This is why we mobilize an additional quantitative approach.

We conducted a large-scale telephone survey ${ }^{7}(2030$ people interviewed; approximately 220 people per fieldwork site) with a sample of inhabitants of the selected territories (interview with one individual per household) in order to collect quantitative data. The survey addressed people's stated ROLEs and their home/work and leisure mobility (excursions, weekend, holidays). The availability of a similar corpus conducted at the same time in Rome and Ile-de-France on the same sample made it possible to identify the specificities of each context (e.g., features related to the layout of agglomerations or to the prevailing culture in both countries) and, conversely, certain similarities (like the existence of similar profiles in both cities in terms of people's stated ROLEs). This quantitative approach made it possible:

1. to create a non-existent database on the long-distance leisure mobility of the residents of these two urban areas,

2. to statistically rebuild and refine a typology stemming from qualitative interviews,

3. to associate shared leisure mobility practices with stated ROLE profiles, and

4. to statistically verify the pertinence of our hypothesis from the point of view of classically advanced indicators (socioeconomic profile and spatial context of the living area), which we will be developing more specifically in this article.

Finally, crossing the contextual analyses of each territory, and the qualitative and quantitative data make it possible:

1. to note down gaps between the context and stated ROLE,

2. to interpret explanatory links between different variables, and

3. to rebuild a posteriori dynamics of mobility compensation like those mentioned in scientific literature (Orfeuil and Soleyret, 2002; Plateau, 2008; ETHEL, 2004-2005; Holden and Norland, 2005) and

4. to better define the structuring elements of these movements.

The analyses presented below reveal the ties that exist between households leisure mobility (in terms of distances traveled) and their socio-economic status, the spatial environment in which they live and their relationship to this environment. The statistical findings presented here are based on bivariate analyses and multiple factor analysis. The dependent variable in this analysis is the number of kilometers traveled for leisure mobility. The independent variables are the characteristics of the spatial context and individuals' ROLE. We will begin by explaining how by elaborating a typology was constructed based on the relationship that individuals have with their living environment and specific mobility practices in terms of kilometers traveled. We will then estimate the advantages gained in terms of statistical explanation by taking into account the spatial context and people's relationship with the living environment. This will be done in three stages:

1. firstly, we will highlight how a household's spatial context affects their leisure mobility; 
2. then we will construct a discrete variable that combines income and education level: socioeconomic status; and lastly

3. using a two-factor variance analysis (geographic location and relationship with living environment), we will study the impact of these two variables on leisure mobility in kilometric terms both separately and in combination, and we will compare their explanatory power to that of socio-economic status.

\section{The urban context and individuals' ROLEs: variables to explain leisure mobility}

We created a typology to test the following assumption: individuals' declared/stated ROLE (as reflected in interviews) affect whether people undertake their leisure activities near or far from their place of residence ${ }^{8}$. We then verified the statistical significance of this indicator in explaining leisure mobility.

\subsection{Creating profiles to define people's stated ROLE}

41 We assume that inhabitants in a given neighborhood generally have different ROLEs. Based on fundamentals elements of the relationships to one's environment obtained by a qualitative method (Table 2), we created a framework to analyze the interviews conducted and classify households according to their "stated ROLE" along three main dimensions: functional, social and sensitivity. In the quantitative analysis, we conducted multiple correspondence analysis (MCA) based on the answers to a set of nineteen questions assessing respondents' satisfaction with living environments (rated on a 4-level scale) and three adjectives (dummy variables) given by respondents to qualify that relationship and how they feel about where they live.

Table 2: Main elements of the relationships to one's living environment obtained by a qualitative method

\begin{tabular}{|l|l|}
\hline $\begin{array}{l}\text { MAIN ELEMENTS } \\
\text { ENVIRONMENT }\end{array}$ & OF THE RELATIONSHIPS TO ONE'S LIVING \\
\hline \multirow{5}{*}{$\begin{array}{l}\text { RELATIONSHIPS } \\
\text { FUNCTIONAL }\end{array}$} & Access to public transportation to railway Station \\
\cline { 2 - 2 } & Automobile accessibility/parking \\
\cline { 2 - 2 } & Accessibility of equipment, services, commercial \\
\cline { 2 - 2 } & Proximity to workplace \\
\cline { 2 - 2 } & Proximity to school \\
\cline { 2 - 2 } & Proximity to cultural place \\
\hline \multirow{2}{*}{ RELATIONSHIPS } & Green space/nature \\
\cline { 2 - 2 } &
\end{tabular}

SENSITIVE 


\begin{tabular}{|c|c|}
\hline & Quiet \\
\hline & Charming place/heritage \\
\hline & Highway Safety \\
\hline & Noises and smells \\
\hline & Landscape \\
\hline \multirow{6}{*}{$\begin{array}{l}\text { RELATIONSHIPS } \\
\text { SOCIAL }\end{array}$} & Reputation and image to the neighbourhood \\
\hline & Community life \\
\hline & Reputation and quality of school \\
\hline & Proximity to family/friends \\
\hline & Neighbourhood atmosphere \\
\hline & Perceived Safety \\
\hline
\end{tabular}

More specifically, factor analysis was carried using the entire set of data concerning the functional, sensitive and social dimensions of the studied relationship. The axis of clustering indicates the variables considered by respondents. This analysis resulted in the definition of five profiles (Nessi, 2012, 2015). The table 3 shows modalities significantly overrepresented (the minimum number five) for each profile.

Villagers (who pay attention to the sensitive and social aspects) are very committed to their living environment, its aesthetics and the possibilities for local sociability existing locally; their day-to-day activities take place primarily within the neighborhood.

Urbanites with local roots (who place value on the functional and social aspects) are very committed to the services available in their neighborhood (commercial services and particularly those related to school and available childcare), as well as to the social atmosphere of their neighborhood.

The homebound in transition (who focus on the functional aspects) are very committed to the public transportation available in their neighborhood, which allows them to access cultural offerings outside their neighborhood of residence. They tend to switch "from home to the city" without being involved in neighborhood life.

46 Metropolitans (who place value on the functional, sensitive and social aspects) are very committed to urban life and the diversity of shops and infrastructure, which is they value highly. While they appreciate their neighborhood, most of their activities are carried outside of the neighborhood, on a much larger scale.

47 Constrained micro-localists (who place value on the social aspect) do not have access to reliable public transportation and are disconnected from the broader territory. They live in their neighborhoods, and sometimes their interactions are even limited to their immediate neighbors. 
Table 3: Socio-economic and living environment characteristics significantly overrepresented for each profile

\begin{tabular}{|c|c|c|c|c|c|}
\hline PROFIL & VILLAGERS & $\begin{array}{l}\text { URBANITES } \\
\text { WITH } \\
\text { LOCAL } \\
\text { ROOTS }\end{array}$ & $\begin{array}{l}\text { CONSTRAINED } \\
\text { MICRO- } \\
\text { LOCALISTS }\end{array}$ & $\begin{array}{l}\text { THE } \\
\text { HOMEBOUND } \\
\text { IN } \\
\text { TRANSITION }\end{array}$ & METROPOLITANS \\
\hline Agglomeration & $\begin{array}{l}\text { Ile-de-France } \\
(<1 \%)\end{array}$ & Rome $(<1 \%)$ & Rome (2\%) & Rome (<1\%) & $\begin{array}{l}\text { Ile-de-France } \\
(<1 \%)\end{array}$ \\
\hline Neighborhood & $\begin{array}{l}\text { Le Thillay } \\
(<1 \%) \\
\text { Limeil- } \\
\text { Brévannes } \\
(<1 \%) \\
\text { Sartrouville } \\
(<1 \%) \\
\text { Emerainville } \\
(4 \%)\end{array}$ & $\begin{array}{l}\text { Cinquina } \\
(<1 \%) \\
\text { Paris-La } \\
\text { Chapelle } \\
(<1 \%)\end{array}$ & $\begin{array}{l}\text { Cinquina }(<1 \% \\
\text { Limeil- } \\
\text { Brévannes } \\
(<1 \%) \\
\text { Pietralata (5\%) }\end{array}$ & $\begin{array}{l}\text { Pietralata } \\
(<1 \%) \\
\text { Testaccio }(3 \% \\
\end{array}$ & $\begin{array}{l}\text { Paris-La chapelle } \\
(<1 \%) \\
\text { Sartrouville (1\%) } \\
\text { Emerainville (2\%) } \\
\text { Paris-La Réunion } \\
(2 \%)\end{array}$ \\
\hline Location & $\begin{array}{l}\text { Periurban } \\
(<1 \%)\end{array}$ & Centre (2\%) & $\begin{array}{l}\text { Peri urban (3\% } \\
\text { ) }\end{array}$ & $\begin{array}{l}\text { Pericentre } \\
(<1 \%)\end{array}$ & Centre $(<1 \%)$ \\
\hline $\begin{array}{l}\text { Income per } \\
\text { household }\end{array}$ & - & - & $\begin{array}{l}<10000 €(<1 \% \\
)\end{array}$ & - & - \\
\hline $\begin{array}{l}\text { Socio- } \\
\text { professional } \\
\text { category }\end{array}$ & $\begin{array}{l}\text { Intermediary } \\
\text { profession, } \\
\text { community } \\
\text { care, } \\
\text { maintenance } \\
\text { service, } \\
\text { health }(<1 \%)\end{array}$ & - & $\begin{array}{ll}\text { Civil service } \\
(2 \%)\end{array}$ & - & $\begin{array}{l}\text { Intellectual and } \\
\text { artistic } \\
\text { professions, } \\
\text { teachers (3\%) }\end{array}$ \\
\hline $\begin{array}{l}\text { Level of } \\
\text { education }\end{array}$ & $\begin{array}{l}\text { No education } \\
(<1 \%)\end{array}$ & $\begin{array}{l}\text { Higher } \\
\text { education } \\
(4 \%)\end{array}$ & - & $\begin{array}{l}\text { Middle } \\
\text { school - }(<1 \%)\end{array}$ & $\begin{array}{l}\text { Secondary } \\
\text { school, (2\%) }\end{array}$ \\
\hline $\begin{array}{l}\text { Types of } \\
\text { housing }\end{array}$ & $\begin{array}{l}\text { Single house } \\
\text { with garden } \\
(<1 \%) \\
\text { Terraced } \\
\text { house with } \\
\text { garden (5\%) }\end{array}$ & - & - & $\begin{array}{l}\text { Building }(<1 \% \\
)\end{array}$ & $\begin{array}{l}\text { Terraced house } \\
\text { with garden (2\%) }\end{array}$ \\
\hline $\begin{array}{l}\text { Occupancy } \\
\text { status }\end{array}$ & - & - & - & - & - \\
\hline
\end{tabular}




\subsection{Leisure mobility shaped by multiple factors: the statistical influence of people's stated ROLE on leisure mobility}

In order to compare the explanatory contribution of our new "stated ROLE" indicator to that of socio-economic characteristics, we created a summary variable called "socioeconomic status based on two multiple correspondence analyses (MCA).

1. The first MCA combined: income per household consumption unit divided into three categories (low, medium and high income); level of education of respondent, divided into three categories (middle school, secondary school, higher education); and socio-professional category, which created three distinct variables including two with three categories and a third, namely socio-economic classification, with 11 categories.

2. The second MCA included only the first two variables. Of these two multiple correspondence analyses, the second was retained since the first two significant factor-based axes accounted for $60.64 \%$ of the variance (which is very high) against only $21.08 \%$ when socio-professional category was also taken into account ${ }^{9}$.

Table 4: Contribution of categories to the two factor-based axis.

\begin{tabular}{|c|c|c|}
\hline & $\begin{array}{l}\text { Axe } 1 \\
(+34,09 \%)\end{array}$ & $\begin{array}{l}\text { Axe } 2 \\
(+26,55 \%)\end{array}$ \\
\hline \multirow{3}{*}{$\begin{array}{l}\text { POSITIVES } \\
\text { CONTRIBUTIONS }\end{array}$} & Graduate studies $+25,21 \%$ & $\begin{array}{l}\text { Livel of education < BEPC } \\
+27,63 \% \\
\text { (equivalent to GCSE) }\end{array}$ \\
\hline & $>17000$ euros $+23,61 \%$ & $>17000$ euros $+9,22 \%$ \\
\hline & 10500 to 17000 euros $+0,30 \%$ & $<10500$ euros $+5,37 \%$ \\
\hline \multirow{3}{*}{$\begin{array}{l}\text { NEGATIVES } \\
\text { CONTRIBUTIONS }\end{array}$} & $<10500$ euros $-26,10 \%$ & 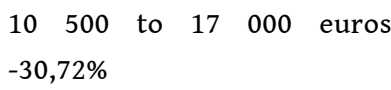 \\
\hline & $\begin{array}{l}\text { Livel of education }<\text { BEPC }-17,58 \% \text { (equivalent } \\
\text { to GCSE) }\end{array}$ & Secondary school $-24,09 \%$ \\
\hline & Secondary school -7,21\% & \\
\hline
\end{tabular}

The table shows, for the first two axes, parents' contributions (positive and negative) of the categories. Non-answers were ignored.

The MCA leads to a classification on the first two factor-based axes based (Table 4) on three socio-economic positions (SEP): the most well-off households (SEP ++) which includes 593 respondents in Ile-de-France and 70 in Rome among respondents to the telephone survey; respondents of medium status (SEP +) which includes 400 respondents in Ile-de-France and 85 in Rome; and households of lower socio-economic status (SEP -) which includes 425 respondents in Ile-de-France and 225 in Rome. It is worth noting that the Roman and Parisian populations are unevenly spread across the three socio-economic classifications; this is due to the large difference in average household income since households in the Parisian region earn an average of 4000 euros more per year than those 
in Rome ${ }^{10}$ (Eurostat, 2010). We thus identified the role of the "socio-economic position" in explaining the distances covered in the context of leisure mobility. As socio-economic status increases, so too does leisure mobility in terms of frequency and distances traveled; and socio-economic status accounts for $90.2 \%$ of leisure mobility.

Table 5. Averages of the Total km_Leisure variable for each pair of citations

\begin{tabular}{|l|l|l|l|l|}
\hline & Central & Peri-central & Peri-urban & TOTAL \\
\hline Metropolitan & 6578 & 6547 & 6650 & 6590 \\
\hline Urbanite with local roots & 6886 & 4266 & 5110 & 5561 \\
\hline Villager & 5005 & 6044 & 5217 & 5498 \\
\hline The homebound in transition & 6495 & 5694 & 2661 & 5434 \\
\hline Constrained micro-localist & 4825 & 5098 & 4506 & 4802 \\
\hline TOTAL & 6386 & 5508 & 5261 & 5719 \\
\hline
\end{tabular}

We then conducted variance analysis in order to ascertain the explanatory contribution of the "geographic location" and the "stated ROLE" (Table 5 and 6). We show that taken separately, "stated ROLE" and "geographic location" are very significant in helping explain the distances traveled. On average, residents of city centers travel much more for leisure purposes than the other respondents. Furthermore, there is a synergy between the two explanatory variables: in addition to their respective influence, their combination also accounts for a portion of leisure mobility. In this two-factor analysis of variance, "stated ROLE" very significantly accounts for $31.5 \%$ of the variance in leisure mobility; geographic location is also very important and accounts for $43.6 \%$ of the variance; and interaction between the two factors accounts for $18.10 \%$; the remaining residual variance $(6.8 \%)$ which reflects the remaining part that cannot be explained by statistically the model is very low (Table 6).

$\mathrm{SCE}_{\text {total }}^{11}=\mathrm{SCE}_{\text {facteur1 }}+\mathrm{SCE}_{\text {facteur2 }}+\mathrm{SCE}_{\text {interaction }}+\mathrm{SCE}_{\text {résidu }}$

Table 6: Two-factor analysis of variance: effect of "stated ROLE" and "geographic location" on kilometres traveled in the context of leisure mobility.

\begin{tabular}{|l|l|}
\hline $\mathrm{SCE}_{\text {total }}$ & 540529578,43 \\
\hline $\mathrm{V}_{1 \text { Stated relationship to living environment_inter }}$ & $31,5 \%$ \\
\hline $\mathrm{V}_{2 \text { Geographic location_inter }}$ & $43,6 \%$ \\
\hline $\mathrm{V}_{\text {interaction }}$ & $18,10 \%$ \\
\hline $\mathrm{V}_{\text {résidu_intra }}$ & $6,8 \%$ \\
\hline Total explication & $93,2 \%$ \\
\hline
\end{tabular}


51 Taken together, the "stated ROLE" and "geographic location" variables give a better statistical prediction of the distances traveled in the course of leisure mobility than socioeconomic status alone, i.e. $93.2 \%$ versus $90.2 \%$. This demonstrates the relevance of our approach. Obviously, we realize the fact that the "stated ROLE" variable is more difficult to build up than socio-economic variable. However, the "stated ROLE" variable is more useful to guide public policy and urban planning than any socio-economic variable.

\subsection{Mobility practices that differ by profile}

The analysis above confirms our hypothesis that people sharing the same living environment but having different relationships to it display different spatial practices (Diagram 1). Indeed it shows that this relationship has a very strong influence on leisure mobility. The leisure mobility of metropolitans is far greater than that of all the other profiles, and the mobility of constrained micro-localists is far less. While villagers, urbanites with local roots and homebound in transition households all have near equivalent leisure mobility, but their travel behavior does not follow the same temporal patterns: villagers travel a longer distance on holidays and the other two during weekends.

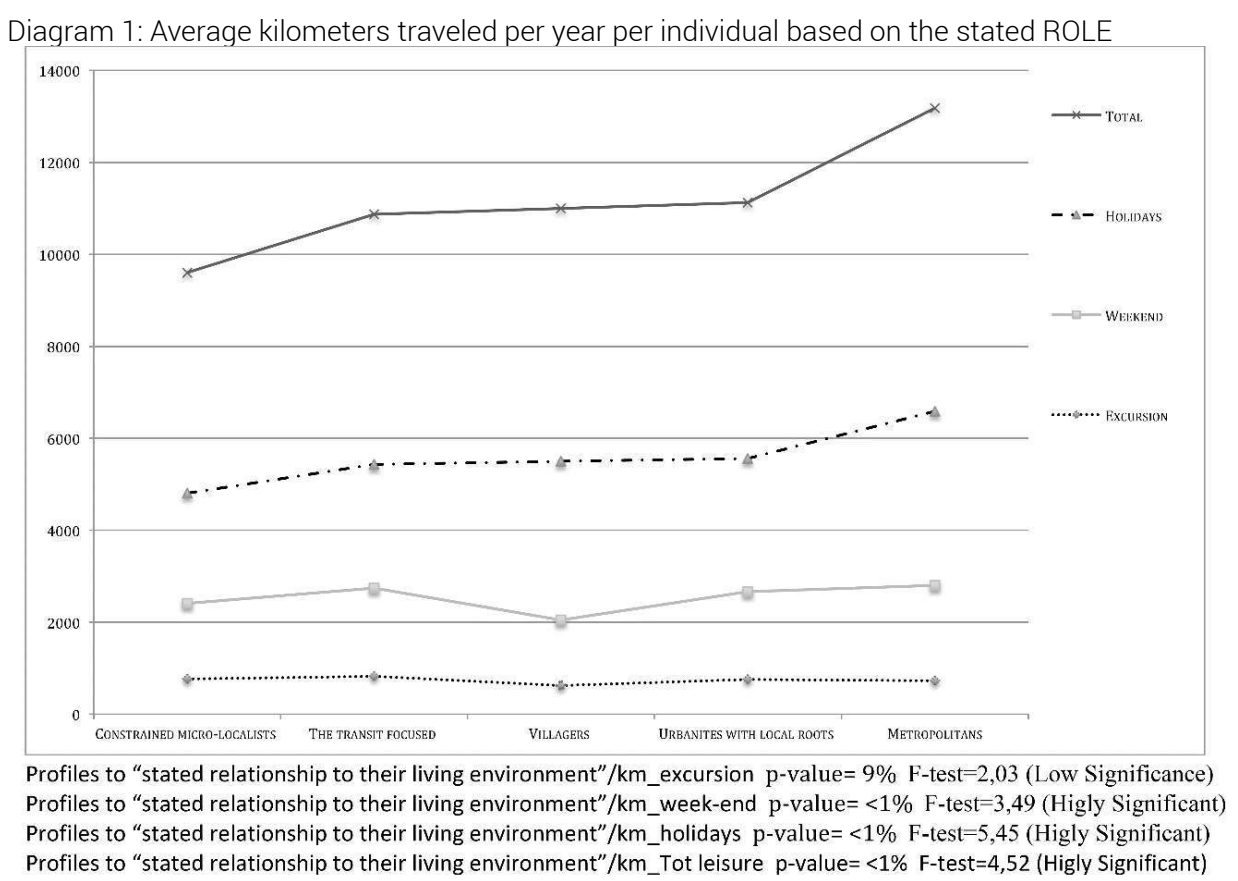

The statistical connection between respondents' stated ROLE and leisure mobility explains why individuals living within the same urban context can have very different mobility practices. More specifically, certain practices noted as being specific to the center or the peri-urban area by some authors (Authier, 2008; Allen, 2007) do not, in our analysis, turn out to be characteristic of only one geographic location.

The different profiles involve different uses of space and mobility practices in terms of the distances covered as well as of the places visited. Defining the five profiles underlines a very strong difference in how the urban context is appropriated by different individuals. A low socioeconomic position combined with an isolated living space badly linked to centralities, explains clearly why people are subjected to rooting accompanied 
by high social attachment, to compensate for the lack of local material resources. On the other hand, for individuals with intermediary or well-off socio-economic positions, indicators explaining the scale of spatial alignment of leisure practices mainly have to do with the stated ROLE.

"Finally, we are well serviced, yes, we have a park across the street, but it is not sufficient. What bothers me in this suburb is the lack of security and the lack of maintenance. We must feel safe in the suburb; we must feel good, and not have the impression that we should be concerned by something; we must feel at ease, we must not feel stressed because we know that some of the people living here are not nice. Here, as soon as we step out of the house, there is drug trafficking. When we go to the park, it's dirty and those people who arrive at Gare du Nord and who spend the night in the station bum around or sleep on the floor. Poor them, I feel sorry for them, but it's not ideal for the children to see this. In fact, we no longer go to this park." Amina - Average income - La Chapelle - Paris/Ile-de-France

Conversely, relationships based more on the social and sensitive spheres often involve less leisure mobility and stronger roots in the place of residence. Shifting from the notion of urban context to that of stated ROLE is an important move, from the point of view of the works of Newman and Kenworthy (1989) or those relying on general categories relating to urban forms or green spaces (Gordon and Richardson, 1997; Orfeuil and Soleyret, 2002; Holden and Norland., 2005; Perrel, 2005). It makes it possible to tackle practices from individuals' representations and to exit spatial determinism. For example, the quality more than the quantity of public or green spaces emerges as essential. It relies on how well maintained the place is, on its accessibility, its establishment in the urban fabric, its exposure to noise and visitation. Our statistical data tells us that days or weekends represent an opportunity, particularly for constrained micro-localists and the homebound in transition, to compensate for the lack of tranquility, space, and nature in their immediate environment. Of interest are the profiles in the Pietralata suburb, in Rome, where we find that constrained micro-localists are overrepresented (Table 3). While contextual analyses show an important presence of green areas and nature, the satisfaction of these two profiles as regards green spaces is lower than the average satisfaction of interviewees. Based on qualitative interviews, we learn that, although green areas surround this suburb, it suffers from abandonment, and that the important stretch of the agro-romano makes keeping up with vegetation and maintaining cleanliness difficult. For these reasons, interviewees as being unsuitable indicated these spaces. Concerning the calm and tranquility in the area, interviewees recall the bad reputation of the suburb dating back to the 1990s, when the unemployed youth came to the green areas to sell and take drugs. As a legacy of this past, the residents' feeling of insecurity is relatively high.

"This is an old suburb. It's in a state of disrepair; the other day for example, after we had a storm and a lot of wind, trees fell last Monday. Today is Friday, the end of the week, and they still haven't been cleared. The municipality is not really concerned about what happens in the suburb. It's an abandoned suburb, dirty and old. On weekends, we go to spas in the Abruzzes, in the Lazio region, towards the lakes. We look for a change of scenery, to be in nature and to see the family. We go there by car, it's more practical. We want a change of air; the suburb weighs heavy on us, the noise but also the people around us." Chiara - Average income - Pietralata 
Moreover, this notion shift made it possible for us to discover the importance of the social sphere, which was little developed, until then, in research works on long-distance leisure mobility. The compensation effect of the social sphere concerns essentially the homebound in transition. Recalling social "compensation" requires a few precautions, since the social domain does not refer to concrete offers, to spaces or some aesthetic quality but, rather, to personal elements relating to social networks as raised by Axhausen (2008). This phenomenon of social sphere "compensation" appears especially during weekend mobility. The destination does not vary according to urban settlements and the quality of the offer, since this network, established outside suburb characteristics, is the reason why residents travel in the first place. Residents visit families and friends in a specific place that, in reality, does not depend on the characteristics of the suburb or the choice of households. Nevertheless, residents who forged friendships or who became integrated into the life of the suburb, thanks to associations or religious communities, are supposedly more attached to the place where they live and feel less the need to leave their suburb to visit family members or friends during weekends. As such, social compensation is influenced by the location of the social network, but also by what associations have to offer in the suburb.

These relationships with the urban context also allow us to understand that some similar practices have different meanings. For example, while homebound in transition households and villagers both spend a lot of time at home, the latter are very attached to their homes while the former see their homes as a place of isolation during the week from which they seek to escape as soon as possible at the weekend.

\footnotetext{
"During the week, we stay at home a lot and the weekend, for the children, we try to go to places they like, in parks and leisure areas. We go to the Valde-Marne, we have family there. Indeed, there are more green areas there. In any case, we try to get out of Paris." Latifa - Average income - Paris

"I've lived in Paris before, as well as in Courbevoie, Lyon... I'm talking about living in France... I think that Sartrouville is the suburb where I made the most friends. (...) They are more than friends, they become family."; "We often invite one another on Saturdays, in the suburb, for a meal. I mean every weekend." Flora - Average income - Sartrouville
}

Beyond the different distances covered, it is also interesting to note the different uses of space (home, immediate vicinity, neighborhood, agglomeration, national and international scales) depending on temporality (Monday to Friday, weekends and holidays) amongst the different profiles and different modal practices (Figure 3). For example, holiday trips represent the main share of all kilometers traveled for leisure. The metropolitans and villagers are those who move the most during the holidays. The metropolitans and villagers, overrepresented in the Ile-de-France, have different social features. Metropolitans are a socially privileged group, whereas villagers come mainly from the working class or lower categories of civil servants, with a relatively low income. Distances traveled seem less influenced by income level than by travel motives. Indeed, villagers tend to travel abroad more during their holidays (Portugal, Spain, Italy, North Africa, etc.) to meet their families or return to their country of origin, whereas metropolitans travel abroad primarily for touristic reasons (the search for "exoticism" and "new horizons"). 


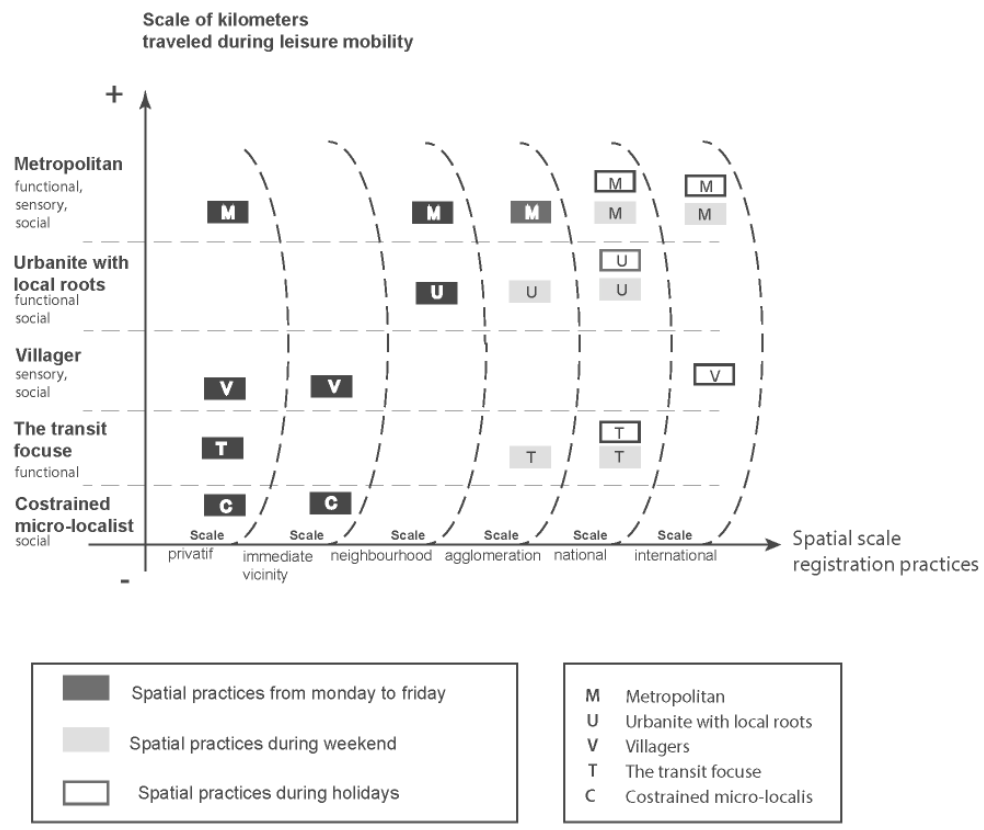

12

Lastly, understanding people's stated ROLE allows us to move beyond a strictly statistical vision of mobility to actually examine leisure mobility practices, i.e., to move towards a subjective and sensitive approach and to identify the meaning and drivers of leisure mobility. Urban context is a resource that should be considered, but the diverse ways in which people use it - as a result, in particular, of their stated ROLE - produces a system of spatial preferences that should also be taken into account. People's practices obviously reflect their socio-economic status, but they also reflect the interaction between individuals and places (an interaction that differs according to individuals' preferences and their ability to appropriate accessible places).

\section{CONCLUSION}

Our research drew on conclusions about the limits of a strictly quantitative approach to understand the influence of urban context on leisure mobility. In order to grasp the sensitive and social relationships that connect individuals to territories, we adopted a hybrid approach that allowed us to statistically test our hypothesis concerning the influence of individuals' stated relationship with one's living environment on their leisure mobility, and to qualitatively understand how the meaning people give to places impacts their choices of destination. By studying the relationships that individuals (in households with young children) have to their living environment in different urban contexts, we explained the differences and variations in mobility amongst individuals in similar locations and with similar socio-economic status.

61 This research shed light on the opportunities and constraints that individuals face when rooting their practices in a territory, according to their social and economic resources, 
their stated ROLE and the specificities of the urban context. While socio-economic status has a stand-alone effect, there are other explanatory variables that can be found in characteristics related to the broader urban context. These combine different aspects related to subjective spheres - the functional (in part subjective), sensitive and social spheres - and no longer deal solely with the physical and objective spheres. We used people's "stated ROLE" to further our understanding of leisure mobility by identifying five profiles which display distinct mobility practices. Finally, a given urban context may accommodate very different practices and very diverse life projects. These findings reinforce the idea of "affordance", i.e., the idea that all urban settings are not equally suited to host a wide diversity of practices and life projects. Our typology of people's stated ROLE allowed us to move away from deterministic explanations for leisure mobility.

Of course, this work contains certain limits. Our methodological choices have led us to deal with a specific category of the population (households with couples between 30 and 45 years old with children). It would be pertinent to pursue this work by focusing also on pensioners, considering their financial means and free time or, still, on active young adults without children benefitting from more freedom. Moreover, at a time when development and transport policies must meet sustainability objectives, it would have been interesting to translate the mobility of the profiles into a $\mathrm{CO} 2$ emission balance. While we know the modes of transport used during each trip, some information on the fill-up rates, the type of vehicles, their age etc., were lacking for us to be able to carry out these calculations. This research could also be pursued by analyzing the leisure mobility of residents in average towns, which would certainly reveal different results to those observed in the two metropolises under study.

Lastly, from an operational perspective, our findings highlight the fact that planning and transport policies have to contend not only with territorial specificities but also with the relationships that individuals have with these territories. A mere transposition of paradigms and dissemination of "good practices" will achieve nothing if they do not go hand in hand with an increased focus on the specificities of urban contexts, as well as on the relationships that individuals have with such contexts. The different profiles of individuals that capture people's stated ROLE highlight the way individuals spread across cities and how they appropriate these cities and use their resources to contribute to urban life. Thinking about the rehabilitation of local publics spaces is a commendable way of improving quality of life and addressing the aspirations of households more effectively so that instead of being subjected to public policy goals for reducing mobility, people actually embrace them due to the presence of a certain number of urban amenities and to individual preferences for using some local places over others that are farther away. 


\section{BIBLIOGRAPHY}

ALLEN, B. (2007). « Le quartier à l'articulation d'enjeux spatiaux temporels », in AUTHIER, J-Y., BACQUE M-H. et F. GUERIN-PACE (ed.), Le quartier. Enjeux scientifiques, actions politiques et pratiques sociales, Paris, La Découverte, p. 139-162.

AUTHIER, J.Y. (2008). « Les citadins et leur quartier. Enquête auprès d'habitants de quartiers anciens centraux en France ", L'année sociologique, 2008/1, vol. 58, p. 21-46.

AUTHIER, J.Y. (2007). « La question des « effets de quartier » en France. Variations contextuelles et processus de socialisation », in AUTHIER, J.Y., BACQUE M.H. et F. GUERIN-PACE (ed), Le quartier. Enjeux scientifiques, actions politiques et pratiques sociales, Paris, La Découverte, p. 206-216.

BANISTER, D. et K. BUTTON (1993). Transport, the Environment, and Sustainable Development, London, Spon Press, 296 p.

BONAIUTO, M., F. FORNARA et M. BONNES (2003). « Indexes of perceived residential environment quality and neighbourhood attachment in urban environment: a confirmation study on the city of Rome ", Landscape and urban Planning, no 65, p. 41-52.

BONAIUTO, M., F. FORNARA et M. BONNES (2006). « Perceived residentiel environment quality in middle-and low-extension italian cities », Revue Européenne de la psychologie appliquée, no 56, p. 23-34.

CAILLY, L. et R. DODIER (2007). « La diversité des modes d'habiter des espaces périurbains dans les villes intermédiaires: différenciations sociales, démographiques et de genre », Norois, vol.4, no 205 , p. 67-80.

CAILLY, L. (2014). « Les habitants du périurbain tourangeau à l'épreuve d'un changement de modèle : vers une recomposition des modes d'habiter ? L'exemple des habitants de la ZAC des Terrasses de Bodets à Montlouis-sur-Loire ", Norois, vol.2, no 231, p. 75-90.

CARPENTIER, S. (2007). « Comportement de mobilité et ancrage résidentiel », Les mobilités quotidiennes: représentations et pratiques. Vers l'identité de déplacement. Rapport final, ATIP no 41799, p. 19-47.

CERVERO, R. et K. KOCKELMANN (1997). « Travel demand and the 3 Ds: density, diversity, and design », Transportation Research Part D 2, no 3, p. 199-219.

CHAMBOREDON, J.C. et M. LEMAIRE (1970). « Proximité spatiale et distance sociale», Revue française de sociologie, no XI, p. 3-33.

COULAGEON, P. et P.M. MENGER (2002). « Les loisirs des actifs: un reflet de la stratification sociale ", Economie et Statistiques, no 352-353, p. 39-55.

COUTURIER, P. (2014). « Mobilité et territorialité dans les espaces ruraux faiblement peuplés: l'injonction à la mobilité face aux modes d'habiter ", Recherche Transports Sécurité, no 2-3, p. 209-221.

DIELEMAN, F.M., M. DIJST et G. BURGHOUTWT (2002). « Urban Form and Travel Behaviour : Micro-level Houseold Attributes and Residential context », Urban Studies, no 39(3), p. 507-552.

DUBET, F. (1994). Sociologie de l'expérience, Paris, Seuil, 271 p. 
DUMAZEDIER, J. (1988). Révolution culturelle du temps libre, 1968-1988, Paris, Méridiens, Klincksieck, $313 \mathrm{p}$.

DUMONTIER, F. et J.L. PAN KÉ SHON (2000). « Enquête Emploi du temps 1998-1999. Description des activités quotidiennes », Insee-Résultats Consommation-Modes de vie, no 101-102.

MORICE, N., J.P. TRAISNEL, K. DELVERT, S. MACRAIGNE, P. POCHET (2004-2005). ETHEL, Énergie, Transport, Environnement, Localisations, Rapport 1 et 2.

FAN, Y., et A. KHATTAK (2009). « Does urban form matter in solo and joint activity engagement? », Journal of Landscape and Urban Planning, no 92, 3-4, p. 199-209.

FEILDEL, B. et D. MARTOUZET (2014). « Le sens des circulations: le sens vécu, objectivé et pratique des mobilités spatiales, Recherche Transports Sécurité, vol. 2014, no 2-3, p. 121-124.

GARFINKEL, H. (1967). Studies in ethnomethodology, NJ, Prentice-Hall, Englewood Cliffs, 288 p.

GORDON, P. et H.W. RICHARDSON (1997). « Are Compact Cities a Desirable Planning Global? », Journal of the American Planning Association, vol. 63, no 1, p. 95-106.

GREFMEYER, Y. (2007). « Le quartier des sociologues », in AUTHIER, J-Y., M-H. BACQUE et F. GUERIN-PACE (ed.), Le quartier. Enjeux scientifiques, actions politiques et pratiques sociales, Paris, La Découverte, p. 21-31.

GRIMAL, R. (2010). « Mobilité à longue distance: plus de voyages s'effectuent en train, mais les seniors restent adeptes de la voiture ", La Revue du CGDD La mobilité des français panorama issu de l'enquête nationale transports et déplacements 2008, Commissariat général du développement durable, $123 \mathrm{p}$.

HALLEUX, J.M. et J.M. LAMBOTTE (2006). « Comment limiter la demande en mobilité et la dépendance automobile par l'aménagement du territoire? » Les cahiers du CEPESS, no 1, p. 23-43.

HOLDEN, E. et I. NORLAND (2005). « Three Challenges for the Compact City as a Sustainable Urban Form: Household Consumption of Energy and Transport in Eight Residential Areas in the Greater Oslo Region », Urban Studies, vol. 42, no 12, p. 2145-2166.

Instituo Nazionale di Statistica, (2008). «Viaggi e vacanze in Italia e all'estero », Statistiche in Breve . JODELET, D. (2006). « Place de l'expérience vécue dans le processus de formation des représentations sociales », in HASS V. (ed.), Les savoirs du quotidien. Transmissions, appropriations, Rennes, Les Presses universitaires de Rennes, p. 235-255.

LANZENDORF, M. (2002). « Mobility styles and travel behaviour - Application of a lifestyle approach to leisure travel », Transportation Research Record, no 1807, p. 163-173.

LEVINSON, D.M. et A. KUMAR (1997). « The Rational Locator: Why Travel Times Have Remained Stable ", Journal of the American Planning Association, no 60, p. 319-332.

LEVY, J. (2003). « Capital spatial », Dictionnaire de la géographie et de l'espace des societies, Belin, Paris, p. 124-126.

LIMTANAKOOL, N., M. DIJST et T. SCHWAMEN (2006). « The influence of socioeconomic characteristics, land use and travel time considerations on mode choice for medium- and longerdistance trips », Journal of Transport Geography, no 14, p. 327-341.

LYNCH, K. (1981). Good city form, Cambridge, MIT Press, 524 p.

MÉYÈRE, A., J. COUREL et C. COUDERC (2006). « Les Déplacements de fin de semaine. » Les Cahiers De l'Enquête Globale Transport. 
NAESS, P. (1995). Urban form and energy use for transport. A Nordic experience, Oslo, NTH, vol. 10 , no $4,187 \mathrm{p}$.

NAESS, P. (2005). « Residential locations affects travel behavior-but how and why? The case of Copenhagen metropolitan area », Progress in Planning, no 63, p. 167-257.

NASAR, J.L., (2000). « The evaluative image of places », in WALSH, W.B., K.H. CRAIK, R.H. Price (ed.), Person-environment psychology. New directions and perspectives, London, Lawrence Ertlbaum Associates, p. 117-168.

NESSI, H. (2012). Influence du contexte urbain et du rapport au cadre de vie sur la mobilité de loisir en Ile-de-France et à Rome. Thèse de doctorat Université Pari/Est, 805 p.

NESSI, H. (2015). « Le rapport à l'espace pour dépasser l'opposition entre ancrage et mobilité », Cahiers scientifiques des transports, no 67, p. 3-32.

NEWMAN, P. et J. KENWORTHY (1989). Cities and automobile dependence, Gower, Aldershot, Royaume-Uni, $406 \mathrm{p}$.

OHNMACHT, T., K. GÖTZ et H. SCHAD (2009). « Leisure mobility styles in Swiss conurbations: construction and empirical analysis », Transportation, no 36, p. 243-265.

ORFEUIL, J.P. (1999). La mobilité : Analyses, représentations, controverses. Mémoire de thèse d'habilitation, Université Paris XII- Val de Marne, 345 p.

ORFEUIL, J.P. et D. SOLEYRET (2002). «Quelles interactions entre les marchés de la mobilité à courte et longue distance?", Recherche Transport Sécurité, no 76, p. 208-221.

ORFEUIL, J.P. (2008). Une approche laïque de la mobilité, Paris, Éditions Descartes \& Cie, 173 p.

PAULO, C. (2006). Inégalités de mobilités: disparité des revenus, hétérogénéité des effets, Thèse de doctorat Université Lumière Lyon 2 Faculté de Sciences Économiques et de Gestion, 392 p.

PERRELS, A. (2005). « Grappling with hybrid structures in sustainable consumption modelsdisentangling urbanity and lifestyle », in HERWITCH E., T. BRICENO, P. HOFSTETTER et A. INABA (ed.), Sustainable Consumption : the Contribution of Research, Workshop, 10-12 February, Oslo, p. 266-307.

PLATEAU, C. (2008). « Les émissions de gaz à effet de serre des ménages selon les localisations résidentielles. Les exemples de la région IDF et de l'arrondissement de Lille. ", Économie de l'étalement urbain. Point de repère, Ministère de l'écologie, du développement et de l'aménagement durable, $112 \mathrm{p}$.

POTIER, F. (2006). Problématique des flux de transport: Mobilité Loisir-Tourisme. Note de travail. POUYANNE, G. (2004). Forme urbaine et mobilité quotidienne. Thèse d'État ès Sciences Économiques, Université Montesquieu-Bordeaux IV, France, 316 p.

PRONOVOST, G. (2014). « Sociologie du loisir, sociologie du temps », Temporalités, http:// temporalites.revues.org/2863 (consulté le 18 mai 2017)

RAMADIER, T. (2007). « Mobilité quotidienne et attachement au quartier : une question de position? », in AUTHIER, J.Y., BACQUE M.H. et F. GUERIN-PACE (ed.), Le quartier. Enjeux scientifiques, actions politiques et pratiques sociales, Paris, La Découverte, p. 127-139.

ROBINSON, J., ANDREYENKOV V-G. et PATRUSHEV V-D. (1988), Time for life :the surprising ways americans use their time, University Park, Pennsylvannia State University Press, $402 \mathrm{p}$.

SCHLICH, R. et K.W. AXHAUSEN (2002). « Wohnumfeld und Freizeitverkehr - eine Untersuchung zur Fluchttheorie », Arbeitsberichte Verkehr- und Raumplanung, Zürich IVT, ETH, no 155. 
SCHLICH, R., S. SCHÖNFELDER, S. HANSON et K.W. AXHAUSEN (2004). « Structures of leisure travel: Temporal and spatial variability », Transport Reviews, no 24, p. 219-237.

STAUFFACHER, M., SCHLICH R., AXHAUSEN K.W. et R.SCHOLZ, (2005). « The diversity of travel behaviour: motives and social interactions in leisure time activities », Arbeitsberichte verkehr- und raumplanung, Zürich, IVT, ETH.

STEAD, D., K. WILLIAMS et H. TITHERIDGE (2000). « Land use, transport and people: Identifying the connections ", in WILLIAMS K., E.BURTON et M. JENKS, Achieving Sustainable Urban Form, London, E \&FN Spon, p. 174-186.

SZALAI, A. (1972), The Use of Time: Daily Activities of Urban and Suburban Populations in Twelve Countries, Mouton, La Hague, 868 p.

TITHERIDGE, H., P. HALL et D. BANISTER (2000). « Assessing the sustainability of urban development policies », Sustainable Urban Form, p. 149-159.

TOURAINE, A. (1995). La formation du sujet, in DUBET, F. et M. WIEVIORKA, Penser le sujet. Autour de l'œuvre d'Alain Touraine. Colloque de Cerisy. Paris: Fayard.

URRY, J. (2000). Sociologie de Mobilités : Une nouvelle frontière pour la sociologie ?, Paris, Armand Colin, 256 p.

VIARD, J., F. POTIER et J.D. URBAIN (2002). La France du temps libre et des vacances, Edition de l' aube, série bibliothèque des territoires, $226 \mathrm{p}$.

WILLIAMS, M., W. EUGSTER, E.B. RASTETTER, J.P. MC FADDE, F.S. CHAOPIN, (2000), « The controls on net ecosystem productivity along an arctic transect: a model comparison with flux measurements ", Global Change Biol., no 6 (Suppl.), p.116-126.

\section{NOTES}

1. Long-distance mobility is defined as all travel at least $80 \mathrm{~km}$ from home (as the crow flies) or travel that involves at least one night away from home or whose destination is abroad.

2. For Grimal (2010), "leisure" trips correspond to a broad spectrum of activities that includes excursions to a leisure centre or amusement park, outings to restaurants, shows and sporting activities, as well as short weekend trips that may be facilitated by a reduction in the duration of annual working time. Leisure trips are however clearly different from "holiday" travel, which corresponds to long trips. "Leisure" activities increasingly involve nights spent away from home. The author distinguishes here between visiting family and friends, and other leisure motives.

3. Long-distance mobility for private trips ( $50 \%$ of the overall mobility) and daily leisure mobility and visits to friends and family ( $10.2 \%$ of the overall mobility).

4. With a preference for regions Lombardia, Lazio, Toscana, Emilia Romana e Veneto Primeggiano.

5. From 2007 to 2008, International leisure travel remains stable. These destinations are mainly European: France (19.6\%), Spain (10.2\%) and Germany (6.3\%).

6. The term "way of living" itself embodies the idea of practices, behaviour, ways of doing things, similar to expressions such as lifestyle or mode of production, for example. More recently, Laurent Cailly (2014) has defined ways of living as a spatial relationship with society and an evolving relationship within the different scales of a territory.

7. The telephone survey used for this quantitative analysis was sub-contracted to survey firm (Alyce Sofreco). Data collection took place between September 2010 and February 2011. The data were analyzed between March and October 2011. 
8. This typology was not based on individuals' mobility or on characteristics related to the urban context, but rather on the relationship that people have to their living environment.

9. This low rate of variance explanation is related to the intra-class distribution (high average distances of observations at the centre of their respective category), the high inter-class dispersion (average distance of categories that are weak amongst themselves) and given the large number of categories (due to the 11 categories in the socio-economic classification variable, versus 3 in the other two variables).

10. If we consider purchasing power, there is an even greater difference (5000 euros/year more revenue for Parisians compared to Romans) due to the price of real estate, which is higher in Rome than Paris/Ile-de-France (Eurostat, 2010).

11. SCE: somme des carrés des écarts.

12. Figures et tableaux sont issus de Hélène NESSI - Source des données: NESSI, H. (2012) influence du contexte urbain et du rapport au cadre de vie sur la mobilité de loisirs en Ile-deFrance et à Rome. Thèse de doctorat Université Paris/Est.

\section{ABSTRACTS}

In this article we examine how (alongside with other factors) the relationship that individuals have to their living environment affects their leisure mobility. We first elaborate a typology (comprising 5 types) of individuals according to their stated relationship to their living environment. Using a statistical approach, we then show that this typology partially explains inter-individual differences in leisure mobility, after taking into account other socioeconomic and spatial explanatory factors: income, level of education, profession, residential location (esp. density of residential area) and demographic characteristics. This statistical argument is complemented with a qualitative study of the meanings given by individuals to their living environments and leisure mobility practices, which ultimately contributes to better understand the drivers of leisure mobility and to emphasize in particular the notion of compensatory mobility. A given urban context may accomodate very different practices and very diverse life projects and the approach developed in the paper has allowed to move away from deterministic explanations for leisure mobility.

Cet article analyse comment (aux côtés d'autres facteurs) le rapport qu'entretiennent les individus à leur milieu de vie affecte leur mobilité de loisirs. Pour cela nous avons constitué une typologie, comprenant 5 profils d'individus, constituée à partir de la relation déclarée de ces derniers à leur milieu de vie. A partir d'une approche statistique, nous montrons ensuite que cette typologie explique en partie les différences de mobilité de loisirs en plus d'autres facteurs socio-économiques et spatiaux: le revenu, le niveau d'éducation, la profession, le lieu de résidence (densité de la zone résidentielle). Cette approche complémentaire contribue finalement à mieux comprendre les facteurs de la mobilité, en dépassant notamment les explications déterministes et souligne en particulier la notion de mobilité compensatoire. 
INDEX

Mots-clés: Mobilité de loisirs, rapport au cadre de vie, pratiques

Keywords: Leisure mobility, relationship to living environment, practices

\section{AUTHOR}

HÉLÈNE NESSI

UMR LAVUE Mosaïque, MCF à Nanterre Paris Ouest-la Défense 